\title{
JUDICIAL ACTIVISM CONTRIBUTING TO THE UNDERSTANDING of Social State Principle(s) - Constitutional Court of Slovenia at the Crossroads
}

\author{
Nejc Brezovar ${ }^{1}$
}

\begin{abstract}
The abstract nature of Constitutional principles, such as the social state principle, requires further interpretation to determine their concrete substance. Their realization is primarily the duty of politics and the legislator. Yet the Constitutional Courts can substantially contribute to developing the contents and nature of social state principles. This paper attempts to show, through examples from Slovenian judicature, how Constitutional Courts can, with the use of (limited) judicial activism, form and shape social politics and their main principles. The Slovenian Constitutional Court is usually relatively restrained in its interpretations of the social state principles respecting the primary authority of the legislator in regulating the area. On the other hand, we cannot ignore the important role the Constitutional Court and its judicature play in developing the substance of social state principles. This is usually done by means of dynamic and evolutionary interpretations. After analysing the judicature, we can conclude that some of the interconnected social state principals developed by the Court, which play a vital role in understanding the essence of a social state and social rights it provides, are: social balance, social security, social justice, solidarity, a minimum protection of existence, prevention of social exclusion, proving the important contribution of Constitutional Courts to the understanding of the concept of social state principals.
\end{abstract}

\section{Keywords}

Social State, Constitutional Principle, Constitutional Court, Judicial Activism, Judicial Self-restraint, Welfare

\section{Introduction}

The social state principle (German: Sozialstaat, French: L'Etat social) is closely linked to the existence of a modern state. Historically, we can place its beginning somewhere in the

${ }^{1}$ University of Ljubljana, Faculty of Administration, Gosarjeva ulica 5, SI-1000 Ljubljana, Slovenia. E-mail: nejc.brezovar@fu.uni-lj.si. 
19th century, when the state began to provide its people with certain public services - the state's part is not only to command but also to perform certain duties, to provide assistance (Duguit, 1919, p. 33). An early example can be seen in the Weimar Constitution of 1919, which in its preamble states its commitment to foster social progress. ${ }^{2}$ There were many attempts to define a social state. When we attempt such a task, we must not confuse the duties of a state with those of the private sector and private institutions. The state's first attempts were to try and regulate the distribution of goods through legislature. Similar attempts in those times were made in different parts of Europe, e.g. England (Polanyi, 1944, p. 144-149) and Germany (Huber, 2006, p. 106). Germany passed several laws regarding social security (health, accident, unemployment, old age insurance) and can be in some ways considered the first historical case of a social state. Many newly founded democracies at the end of the 20th century, especially in Eastern, Central and South Europe proclaimed themselves social states (e.g. Slovenia, Croatia, Germany, Romania, Bulgaria, the Russian federation, FYRM) or states based on the principle of social justice (e.g. Serbia, Montenegro, Poland), dedicating a special chapter of their constitutions to social and economic rights. Nowadays new challenges lie ahead for modern social states, such as fiscal policy, mass unemployment, migrations, globalization and demographic changes. Much has been done by the European Union (Charter of Fundamental Rights of the European Union ${ }^{3}$ ) and Council of Europe (The European Social Charter) to raise awareness of social rights on the European level. Regardless, social policies primarily remain the domain of national states. The German Constitutional Court ${ }^{4}$ concluded that the social state principle is a goal and it is up to the state and the legislator "to carry out this obligation on the basis of a broad discretion". 5

Elements of the social state principle are usually formed outside of courts as representatives of judicial power. Influence on its concept primarily lies within the legislative and executive branches of power. They are both closely linked to different ideologies, holders of power

\footnotetext{
${ }^{2}$ Weimarer Verfassung, Präambel, 1919: »Das Deutsche Volk, einig in seinen Stämmen und von dem Willen beseelt, sein Reich in Freiheit und Gerechtigkeit zu erneuern und zu festigen, dem inneren und dem äußeren Frieden zu dienen und den gesellschaftlichen Fortschritt zu fördern, hat sich diese Verfassung gegeben.«

${ }^{3}$ Official Journal of the European Communities, C 364/1, 18.12.2000.

${ }^{4}$ We should not overlook the fact that the German Constitution (Grundgesetz für die Bundesrepublik Deutschland) from 1949 and its Article 20 on the social state are structural principles, meaning that they represent a guarantee in perpetuity (Ewigkeitsgarantie) and are immune to change, since without them the Constitution would not be the same. For more on the topic, see Tiedmann (2003).

${ }^{5}$ Federal Constitutional Court of Germany judgement BvE 2/08, 2 BvE 5/08, 2 BvR 1010/08, 2 BvR 1022/08, 2 BvR 1259/08, 2 BvR 182/09 (30.6.2009): “... The principle of the social state, however, would oblige the legislature to ensure the balancing of social differences, although it leaves the legislature broad latitude for doing so... Particularly sensitive for the ability of a constitutional state to democratically shape itself are decisions on... fundamental fiscal decisions on public revenue and public expenditure, the latter being particularly motivated, inter alia, by social policy considerations (3), decisions on the shaping of living conditions in a social state (4).. The principle of the social state establishes a duty on the part of the state to ensure a just social order. The state must carry out this obligation on the basis of a broad discretion; for this reason, concrete constitutional obligations to act have only been derived from this principle in very few cases. The state must merely create the minimum conditions for its citizens to live in human dignity. The principle of the social state sets the state a task, but it does not say anything about the means with which the task is to be accomplished in individual cases." For more regarding the German social state, see Heinig (2008).
} 
and their political standpoints. The principle of the social state is often located in national constitutions and is therefore materia constitutionis. As such, it is open to interpretation by the highest national courts, such as constitutional or supreme courts. The influence of these courts on the content of the social state principle should not be neglected since the courts can - with their interpretations and decision-making - crucially change the understanding and the use of a constitutional principle. The influence of the courts depends on their susceptibility to judicial activism on one hand, or their judicial restraint on the other. When using judicial activism, as a means of interpreting constitutional principles, judges should be careful not to violate the separation of powers principle and "legislate from the bench". Some attempts have already been made to explore the impact of constitutional review and judicial activism on fiscal politics (Kantorowicz, 2014). Although the social state, social rights and social policies are closely linked to state fiscal policies, not much has been researched regarding the role of Constitutional Courts in forming and shaping their substance. This was especially evident in the light of recent austerity measures. The way Constitutional Courts can in some part play the role of protector and promotor of social state principles and social rights will be presented using examples from Slovenia.

In its judgements, the Constitutional Court of the Republic of Slovenia (hereinafter Court) often referred to the social state principle. In doing so, it developed different (sub) principles of the latter, but was never too keen on the use of judicial activism in the field of interpreting the context of the social state principle. Although its interpretations were mostly relatively restrained, the Court managed to argue and present the content of different human and social rights with the help of the social state principle.

Comparing the role and influence of the legislator and its legislature in affairs concerning the social state with the judicature of the Court, we can conclude that the latter has a strong impact on the development of the constitutional social state principle and its subprinciples. ${ }^{6}$

\section{The relationship between the constitutional social state principle and its (sub) principles}

Examining the judicature of the Court, we are left to contemplate the substance of the social state principle. Its interpretations often use different principals regarding different human and social rights to help connect them to the general social state principle. Even though many constitutions do not specifically mention the social state, they refer to certain principles deriving from the social state principle, such as solidarity principle, social security principle, etc. The Court inconsistently uses legal terminology, referring at some moments to the "social state principle (singular)" and in others to "social state principles (plural)". The prevailing approach of the Court is one in favour of unity of the social state

\footnotetext{
${ }^{6}$ When arguing for the acceptance of a certain legislature relating to social rights, the legislator does not usually refer its arguments on the social state principle, but rather on different principles and elements that derive from it. One such example is the Pension and Disability Insurance Act (Official gazette 96/12, 39/13, 99/13, from 01.01.2013) which refers to the principle of (intergenerational) solidarity.

${ }^{7}$ Constitutional Court of Slovenia judgement Up-752/07, in which the Court mentions that the duty of the state to provide for the correct legal representation in front of the court of a person that is unable to do it itself is
} 
principle as a singular, general, basic constitutional principal. Yet the occasional usage of the plural signals to the reader the Court's awareness of the complexity of the social state principle structure. The latter principle is a structural principle, a puzzle made up of parts presenting different subprinciples and social rights. The substance of the social state system changes when a new principle sees the light of day. A newly developed principle presents another piece of the puzzle. Many of these subprinciples were developed with the help of the Court judicature, which in time evolved using examples from comparative judicature of foreign constitutional, supreme and international courts and legal theory. It is not relevant whether the Court uses the singular or plural when referring to the social state principle. Nevertheless, it would be recommended that the Court, when using the social state principle as a substantive argument in favour of a concrete decision, specifies on which element or social state (sub)principle the emphasis lies. By doing so the Court would narrow the space for further discussions and determine the principle for the easier development of the substance of this individual principle. In one of its judgements, the Court already classified the solidarity principle as one of the components of the social state principle. ${ }^{8}$ This brings us to the conclusion that the Court understands the social state principle as a singular principal compound of many subprinciples and social rights, which in a broader sense present its integral parts. For example, the concrete right to social security at the same time presents a human right and a constitutional principle. ${ }^{9}$

\section{Heterarchy of social state principles}

Although different (sub) principles and elements of the social state that were developed by the Court or identified by legal theory during the research of the judicature originate from the social state principle, they are not inferior. Some of these principles are: social balance, social security, social justice, solidarity, protection of existence minimum, prevention of social exclusion. ${ }^{10}$ They derive their power and legitimacy from the general principle as their origin. The Court correctly uses the terminology when speaking of social state principles and not subprinciples. When using the term "subprinciple", it signals a certain negative or inferior connotation, which can be deceptive. Using the term subprinciple is therefore only recommended when trying to show the link with the general principle as the origin of a certain (sub)principle. This should not lead us to the conclusion that such a subprinciple is inferior to the social state principle. In fact, we could be dealing with a completely independent principle, the origin of which hides itself in the idea of a social state. The impact of these principles is erga omnes. When the Court develops a certain

a »reflection of the social state principle«.

${ }^{8}$ Constitutional Court of Slovenia judgement U-I-36/00 from 11.12.2003»The solidarity principle is a component part of the social state principle from Article 2 of the Constitution «.

${ }^{9}$ Article 50 Constitution of Republic of Slovenia (Official Gazette RS Nos. 33/91-I, 42/97, 66/2000, 24/03, 69/04, $68 / 06$, and 47/13) »Citizens have the right to social security, including the right to a pension, under conditions provided by law. The state shall regulate compulsory health, pension, disability, and other social insurance, and shall ensure its proper functioning. Special protection in accordance with the law shall be guaranteed to war veterans and victims of war«.

${ }^{10}$ Similar principles were developed in the judicature of the Federal Constitutional Court of Germany. See Huber (2006). 
principle, it is not necessary for the Court to name it - that role can be left to legal theory. The newly developed principle comes to life and separates itself from the general uniform principle. It presents a dynamic evolution of the latter.

One of the principles named by legal theory is the "burdening of social groups according to their capability". The Court itself did not name this principle, but its substance can be found in different Court decisions. In one of them, the Court discussed the pension system and came to the conclusion that "on the side of the active generations not only their income should be taken into account but also the number and social status of the unemployed. The preservation of unreduced value of pensions, what the initiators are arguing for, would lead to unbearable differences between the social status of retired and active generations and doing so to severe violation of the social state principles." ${ }^{11}$. Such principles are especially important in times of financial crisis. When the state needs to lower salaries, pensions or unemployment benefits, it should take into account the latter principle. If such legislature comes in front of the Court, it will use the proportionality test in conformity with the before mentioned principle. This principle would inevitably connect itself with other social state principles, like the prevention of social exclusion principle, etc.

\section{The interaction of social state principles and their time component}

Independent social state principles have different interactions. They often connect to one another, which is not only allowed but is also preferred. These connections exist not only among different principles, but also principles and human and social rights. Procedures in front of the court usually deal with the violation of a specific constitutionally guaranteed right. Different abstract principles serve only as support for arguments leading to a specific conclusion regarding a concrete right. The Court does not protect the principles themselves, but concrete human rights. ${ }^{12}$ Usage of principles and finding of their violations are limited mostly to the Courts using them as arguments to emphasise their conclusions on the violations of concrete human rights in cases of constitutional complaints. ${ }^{13}$ Specific human rights and fundamental freedoms can, in certain aspects, crucially aid in the understanding and enforcing of social state principles in everyday life. The Court came to the same conclusion, often using the connection of different human rights with social state principles, which themselves often connect, interact and intertwine. These intersections are the place where the Court can use an evolutionary and dynamic interpretation of the Constitution, when deriving the substance of social state principles from a concrete human right question.

\footnotetext{
${ }^{11}$ Constitutional Court of Slovenia judgement U-I-31/96 (26.11.1998).

12 Constitutional Court of Slovenia judgement Up-314/99, (12.07.2001).

${ }^{13}$ In one such case (Constitutional Court of Slovenia judgement Up-40/97 (7.3.1997)), based on a constitutional complaint, the Constitutional Court argued that the Right to Judicial Protection (Article 23. Constitution of Republic of Slovenia clearly indicates the prevention of social exclusion principle and the importance of easy access to courts for destitute members of society. The court fees should not present an insurmountable obstacle depriving the destitute of access to courts. The Court therefore understands the Right to Judicial Protection as an important means for preventing social exclusion, which is vital for the protection of certain rights of deprived members of society who often depend on such rights to ensure their existence in dignity.
} 
Social state principles are not immune to the passing of time: they evolve, either by gaining new substance. or by the emergence of a new principle. Their nature therefore is not permanent, unchanging or static. It is lasting, offering some continuity, but susceptible to progress and evolution and therefore dynamic. Constitutional Courts actively participating in such transformation require careful consideration and convincing arguments not to exceed their authority. ${ }^{14}$

\section{Evolutionary and dynamic interpretation combined with judicial activism or judicial restraint}

The Constitutional Court of Slovenia, as already established, is relatively restrained in its judgements, when it comes to interpreting the social state principle, taking into account the wide margin of appreciation reserved to the legislator in regulating the field of social state. Despite this fact, some cases can be found wherein the Court tries to define a certain social state principle substance in more detail using the evolutionary interpretation.

\section{a. Judicial activism prevailing or taking its last breath}

Constitutional courts act as guardians of the Constitution, and have to perform an important role in interpreting and enforcing human rights. Judicial activism, as a way to interpret the constitution, has many meanings and can take many forms (Kmiec, 2004). The first of many forms is abrogation (or annulment) of the legislature or regulations enacted by other (executive or legislative) branches of power. ${ }^{15}$ The highest courts, from the "Kelsenian model" 16 on, are usually attributed the role of negative legislators (Bustamante and de Godoi Bustamante, 2011). Therefore, a large number of abrogations of legislature by the Court do not necessarily present judicial activism. The reason behind most abrogations is an obvious contradiction between the legislature and constitutional norms or between regulations or general acts and the legislature. Those situations in which unconstitutionality or unlawfulness is not so evident are problematic. The role of the Courts in such cases can be debated. Theorists have different standpoints from those arguing that the Court should not be the final interpreter of constitutional norms ${ }^{17}$, up to the position (shared by most legal theorists), that the Court can or even should interpret what law is, even in difficult and politically sensitive issues or cases. ${ }^{18}$

\footnotetext{
${ }^{14}$ Constitutional Court of Slovenia judgement U-I-230/00 (17.4.2003), the Court argued that new social legislation or changes in existing one require a longer transitional period to enter into force so the people affected by it can adapt to changes without worsening the social position of the individuals it affects.

${ }^{15}$ Articles 43 to 45 of Constitutional Court Act (ZUstS), Official Gazette of Republic of Slovenia, No.64/07, official consolidated text, (15. 7. 2007).

${ }^{16}$ Kelsen was convinced that the only role Constitutional Courts could play was the one of negative legislators. For more on the topic, see Kelsen (1945).

${ }^{17}$ For more on the topic, see Kramer (2001), Kramer (2000) and Tushnet (2000).

${ }^{18}$ Even though this point of view of view is shared mostly by legal theorists on the US legal system and the role of the US Supreme Court, we can draw many parallels in connection to constitutional courts as interpreters of constitutional norms (see Kramer, 2001, notes 5 to 9). The first such case, where the US Supreme Court abrogated a law, and which presents a foundation for such judgements is Marbury v. Madison, 5 U.S. (1 Cranch) 137 (1803). Some theorists see as especially problematic judgements relating to political questions, since this
} 
The second form of judicial activism is visible in cases when the Courts ignore a precedent or test case, or when they overturn an already accepted judicial standpoint. Here we are not necessarily dealing with judicial activism. With regard to the Slovenian Constitutional Court judicature, we shall discuss only the question of horizontal precedent (aka horizontal stare decisis), a situation on which the Court had already taken a position, but on which it later, when dealing with other cases, changed its view. Some theorists find judicial activism, in the area of horizontal precedent, inappropriate, while others argue that sometimes it is appropriate to renounce a horizontal precedent. Lawson $(1994$, p. 27) claims that stare decisis can also be unconstitutional if they demand that the Courts abide a wrongful interpretation or reading of the Constitution. He claims that "if the Constitution says X and the prior judicial decision says Y, a court has not merely the power, but the obligation to prefer the Constitution". Most courts would agree with the possibility of changing or setting aside horizontal precedent, when strong reasons and argument exist (to avoid unnecessary criticism claiming unfounded judicial activism) in favour of change. The Constitutional Court of Slovenia does not lightly change its precedents when it comes to the field of social state principles. Instead it rather contributes new substance or develops a new principle with its interpretations in cases and situations that have not yet been discussed. Rare are those cases in which the Court renounced its horizontal precedent. ${ }^{19}$ The third possible form of judicial activism is judicial legislation. Such situations arise when Courts (supreme or constitutional) adopt erga omnes strictly binding effect judgements and in doing so assume the role of the positive legislator. Some authors believe that Courts in such cases (intentionally) violate the separation of powers principle. ${ }^{20}$ Especially problematic is the relation to so-called interpretative judgements, which are used when the disputed norm has a different meaning and is used in different ways, in the practice of which some are constitutionally admissible and some not. Pronouncement of the judgement usually reads that a certain provision or norm "is not unconstitutional, when interpreted as stated in the explication of the judgement" (Testen, 2002, p. 1131). Interpretative judgements can be ones of acceptance or of dismissal and present a way in which the Constitutional Courts exercise their interpretative powers. ${ }^{21}$ They are especially

means the Courts take jurisdiction for decision-making "on all that is constitutional". Kramer and some others are determined opponents of judicial supremacy on political question. See also Tyler (2006).

${ }^{19}$ Such a case was Constitutional Court of Slovenia judgement U-I-147/94, in which the Court renounced the position it took in case U-I-70/92. The Courts first argued that determining permanent residence as a condition for attaining certain social security rights (such as pension benefits) is not discriminatory. The Court later renounced its position. One of the judges (M. Krivic) wrote a dissenting opinion arguing that "social security should be provided for every citizen under the same conditions regardless of their place of residence". This was in connection with Articles 14 (Equality before the Law) and Article 32 (Freedom of movement) of Constitution of the Republic of Slovenia.

${ }^{20}$ In American legal theory, the term »legislate from the bench « is used. Such Court interpretations or judgements which "create law" are in direct contradiction with originalism as a principle of interpretation, since this theory claims that judges should not create law. US Supreme Court judge Antonin Scalia argued in favour of originalism as the most appropriate form of judicial interpretation, since it prevents judicial activism "from the bench". On the other hand, some authors do not see any negative consequences, if judgements are dealing with cases when the legislature, which is in obvious contradiction with basic constitutional principles, does not change for decades in which it might be appropriate for the judge to change/create law. More on the topic in Remington (2002).

${ }^{21}$ For more on interpretative judgements, see Ferrari (2008), p. 201 and 202. 
rare when dealing with situations regarding areas where the national legislator has a wide margin of appreciation - such as social rights. ${ }^{22}$ The Court should refrain from substantive judgements regarding concrete measures taken by the legislator when ensuring and regulating social rights. Similar limitations also exist for the legislator, since he is not allowed to excessively interfere with the core of the constitutionally guaranteed rights. His margin of appreciation might be wide, but it is not unlimited and must be in line with the principle of proportionality. ${ }^{23}$ Due to the abstract nature of constitutional provisions and norms, a general consensus exists in Slovene legal theory that a certain level of moderate judicial activism is required for the courts to properly perform their functions (Jambrek, 1992, p. 341). The Slovenian Constitutional Court, when interpreting the nature and substance of a certain social right or social state principles, does not interpret in such a way that would close off the path for other possible interpretations. Usually it partially defines the substance of a certain social right or principle, leaving some room to manoeuvre to the legislator. Besides the already discussed forms of judicial activism, there exist many more, such as a result-oriented judgement. ${ }^{24}$

\section{b. Judicial (self) restraint - surrender of the Constitutional Court}

The Slovenian Constitutional Court shows less judicial self-restraint ${ }^{25}$ and has a tendency towards judicial activism in cases dealing with legal standings connected to human rights such as social security. The key lies in its duality as a constitutional principle and as a human right assured by Article 50 of Slovenian Constitution. The Court already decided that a social state has - on the basis of the right to social security ${ }^{26}-$ a duty to provide an underprivileged individual with proper assistance and must not endanger this right with unjustified impoverishing of funds for ensuring such assistance. The Court also decided that interference with private property is allowed on the ground of protecting the social security of other citizens. ${ }^{27}$ Such a decision authorises the legislator to intervene, if he

\footnotetext{
22 The doctrine of margin of appreciation permeates the judicature of the European Court of Human Rights and is based on the notion that each society is entitled to certain latitude in resolving the inherent conflicts between individual rights and national interests. For more on margin of appreciation, see Benvenisti (1999) or Tümay (2008).

${ }^{23}$ Similar would be the case of the European Court of Justice in regard to the Charter of Fundamental Rights of the European Union (Official Journal of the European Union C 326/391, 26.10.2012), where the ECJ has a significant role in interpreting the core of a certain fundamental right or principle, which is especially crucial for any "new" rights such as prohibition of discrimination on the grounds of age, sexual orientation etc., where secondary legislation has not been passed in its full potential.

${ }^{24}$ For more on the topic, see Kmiec (2004).

${ }^{25}$ For more on the topic of judicial self-restraint, see Posner (1983). On p. 10, Posner explains the five different senses of judicial self-restraint »(1) A self-restrained judge does not allow his own views of policy to influence his decisions. (2) He is cautious, circumspect, hesitant about intruding those views. (3) He is mindful of the practical political constraints on the exercise of judicial power. (4) His decisions are influenced by a concern lest promiscuous judicial creation of rights result in so swamping the courts in litigation that they cannot function effectively. (5) He wants to reduce the power of his court system relative to that of other branches of government.« ${ }^{26}$ Similar views are shared by the Federal Constitutional Court of Germany (Bundesverfassungsgericht) in BverfGE 28, 324 (27.05.1970 - 1 BvL 22/63; 1 BvL 27/64), which argues that social security is a fundamental reflection of the social state principle and presenting the core of a social state.

${ }^{27}$ Constitutional Court of Slovenia judgement U-I-330/97 (30.11.2000).
} 
sees necessary, in regulating the right to private property ${ }^{28}$. It also indicates that, in the case of the collision of two constitutionally guaranteed rights - to private property and social security - the Court gives preference to the latter. A crucial role here is also played by public interest - the protection of social security of other citizens. In one of its decisions, the Court argued that the social state principle binds the Legislator to pass such legislature, which will ensure the social security of individuals, especially in times when they are unable to earn a living because of personal or economic reasons such as unemployment. ${ }^{29}$ In doing so, the Court determines a duty for the legislator and gives him a signal that, despite the wide margin of appreciation he enjoys, he is not completely autonomous when regulating social rights and relations. At the same time, the Court defines reasons of a personal or economic nature (unemployment) leading to a state in an individual's life when he or she will be unable to earn an income or provide for themselves. The Court lives leeway to the legislator to regulate other areas not explicitly defined and articulated in the judgement. ${ }^{30}$ The explication used by the Court is of an open nature, which can be seen by the usage of the phrase "especially in cases such as...", letting the legislator know that the Court has set a minimum standard and defined situations in which social security must be provided, leaving it up to the legislator whether he decides to widen the list. ${ }^{31}$ Since social security is a human right, it is easier for the Court to refer to it in its judgements, rather than to social state principles. We can conclude that the Court's judgements are more dynamic and evolutionary orientated in cases interpreting social rights as human rights, compared to cases dealing with the "violation" of one of the social state principles where the judgements are restraint.

In some cases, the Court opposes the leading position of the legislator in regulating social rights and social state principles, by narrowing his autonomy and setting boundaries where his wide margin of appreciation ends, in the Court's point of view. As already mentioned, his regulatory activities are not without their limits. Each human right has its constitutionally guaranteed core, which is its essence, and is out of reach of the legislative activities of the legislator. That is why each case must be examined to see whether a legal regulation used to determine the substance of a certain human right present only a way of realizing that right, or if it presents an infringement or a way to narrow the right. ${ }^{32}$ The Court must be especially watchful on this boundary, not allowing the legislator to cross (and violate) it. The Federal Constitutional Court of Germany argues that fundamental measures to ensure the realization of the social state can be taken only by the legislator ${ }^{33}$, which can take appropriate measures to ensure a just social order ${ }^{34}$, keep social peace and

\footnotetext{
${ }^{28}$ Article 33 of Slovenian Constitution »The right to private property and inheritance shall be guaranteed.«

${ }^{29}$ Constitutional Court of Slovenia judgement U-I-94 (18.10.1995).

30 The Constitutional Court does not, for instance, set the amount of unemployment benefit that would ensure the social security of an individual in times of unemployment - such decisions and measures are left to the legislator.

${ }^{31}$ Social security should not, since it exceeds it, be understood as an existential minimum. An existential minimum is required solely for survival, while social security ensures economic safety and human dignity.

${ }^{32}$ Constitutional Court of Slovenia U-I-159/07 (10.6.2010).

33 BverfGE 103, 271, 1 BvR 1681/94, 1 BvR 2491/94, 1 BvR 24/95 (03.04.2001).

${ }^{34}$ BverfGE 110, 412, 2 BvL 5/00 (08.06.2004).
} 
balance social contrasts ${ }^{35} \cdot{ }^{36}$ Court arguments based on social state principles play a vital role in determining the core content of a certain social right, a Rubicon the legislator is not allowed to cross. The legislator enjoys wide discretion to follow constitutionally admissible goals. Consequentially the Court will verify - by means of legitimacy and a strict proportionality test - whether a certain measure is in line with those goals. The Slovenian Constitution does not bind the legislator to adopt a certain regulation or implement certain measures, rather it gives him the possibility to choose - it gives him discretion. The legislator can implement any measure capable of fulfilling his duties. He is bound only by constitutional principles and the duty to respect constitutionally guaranteed human rights and fundamental freedoms - their core. The Slovenian Constitution does not guarantee specifically determined social rights. It is up to the legislator to define the contents of those rights by regulation. The duty of the state extends to providing the conditions and possibilities for realization of social security. ${ }^{37}$ The Court is not officially bound by judicial self-restraint. The latter is a result of its own decision not to interfere in certain relations where it acknowledges the legislator's primary authority. In times of austerity measures, the legislator must take special care not to violate the core of social rights. ${ }^{38}$

The principle of the protection of existential minimum is an example of a "cascade" principle in reference to the origin - the social state principle. The Court, with the help of evolutionary interpretation, develops a principle that originates from the general principle, and comes to live an independent "life", separate from its origin but (inter)connected to it, equal in legal authority. The social security principle is also (inter)connected to the principle of protection of existential minimum and vice versa - which of the principles presents the origin of the other depends on a concrete case or judgement and its argumentation.

The Court can, using the evolutionary interpretation, influence the social state system and change the legislature. The more inventive the Court is in its evolutionary interpretations of the Constitution and its principles, the bigger is its influence on the co-creation of the social state system. With dynamic and evolutionary interpretation, the Court can contribute to the development, and not merely maintenance of status quo in the area of protection of social rights and their social state principle source. ${ }^{39}$ Yet the Court must be appropriately restrained in its actions and judgements, so as not to overly interfere in the area primarily reserved for the legislator.

\footnotetext{
${ }^{35}$ BVerfGE 100, 271, 1 BvR 2203/93, 1 BvR 897/95 (27.04.1999).

${ }^{36}$ This view is also shared by the Constitutional Court of Republic of Croatia in its decision U-I/283/1997 (12.5.1998), where the Court argued that Croatia is a social state and that the legislator should keep that in mind when passing laws which enforce constitutional guarantees for respecting the principles of social security and social justice as one of the highest values of Croatian Constitutional order, even though it is within his authority to independently decide on regulating economic, legal and political situation in the state.

${ }^{37}$ Constitutional Court of Slovenia judgement U-I-282/94 (18.10.1995).

${ }^{38}$ For more on the topic of austerity measures and the social state, see Kingreen (2003).

${ }^{39}$ Evolutionary and dynamic interpretation walking hand in hand with judicial activism have historically at multiple times contributed to the development of certain civil and political rights which are nowadays taken for granted, such as Brown v. Board of Education of Topeka, 347 U.S. 483 (from 1954) on racial segregation legislature in the USA.
} 


\section{Conclusion}

After analysing the judicature of the Constitutional Court of Slovenia, we can conclude that it is (they are) capable of influencing the substance of social state principle(s). In the last decade, we have witnessed declining interest in the social state principles on the part of the Court. The Court nowadays seldom uses judicial activism and by doing so misses the opportunity to further develop social state principles. The main reason for this can be attributed to the awareness of the strict(er) separation of powers, especially legislative and judicial, resulting in judicial self-restraint. One other reason is that most of the social state principles found in comparative judicature were developed and defined in the first decade or so after the adoption of the new constitution in 1991.

The Court, when dealing with social rights in its arguments, often refers to social state principle(s). All individual principles and elements of the social state principle should be treated as equal, together representing the paradigm that is the social state. Their essence is not static but dynamic, since their substance is constantly changing and evolving. The Court is increasingly self-restrained, leaving the primary decision making on the substance of social state to the legislator. Some judicial activism can be seen when it protects the core of a constitutionally guaranteed social right and in the process develops new or defines existing elements of social state principles. The Court, when interpreting the substance of social state principles, applies an evolutionary interpretation, which is inevitably self-restrained. The influence of Constitutional Courts as presented confirms the hypothesis that the Courts themselves are the creators of social state substance to a certain limited extent. Although the Court in its judicature lately has not paid much attention to interpretations of social state principles, it still interprets them in a greater manner than the legislator in its legislative function. The concept and meaning of the social state principles therefore explicitly reflect themselves through the judicature of the Court in which the latter tries to interpret their substance.

\section{References}

Benvenisti, E. (1999). Margin of Appreciation, Consensus, and Universal Standards. New York University Journal of International Law and Politics, 31, 843-854.

Bustamante, T. and De Godoi Bustamante E. (2011). Constitutional Courts as "Negative Legislators": The Brazilian Case. In Ed. Brewer-Carias, A. Constitutional Courts as Negative Legislators. Cambridge: Cambridge University Press.

Duguit, L. (1919). Law in a modern state. Reprint Kessinger Publishing, LLC, 2008.

Ferrari, G. F. (2008). Introduction to Italian Public Law. Giuffrè Editore.

Heinig, H. M. (2008). Der Sozialstaat im Dienst der Freiheit: zur Formel vom "sozialen" Staat in Art. 20. Abs. 1 GG. Mohr Siebeck.

Huber, E. R. (2006). Verfassungsgeschichte 2nd edition (1957-1991). Dreier H. (ed.). Grundgesetz Kommentar, 2. Auflage, Band II. Mohr Siebeck.

Jambrek, P. (1992). Ustavna demokracija. Ljubljana: Državna založba Slovenije. Kantorowicz, J. (2014). Judges as Fiscal Activists: Can Constitutional Review Shape Public Finance? DANUBE: Law and Economics Review, 5(2), 79-104. 
Kelsen, H. (1945). General Theory of Law and State. Cambridge: Harvard University Press.

Kingreen, T. (2003). Das Sozialstaatsprinzip im europäischen Verfassungsverbund. Jus Publicum.

Kmiec, K. D. (2004). The Origin and Current Meanings of "Judicial Activism". California Law Review, Inc. 1441-1478.

Kramer, L. D. (2000). Putting the Politics Back into the Political Safeguards of Federalism. 100 Columbia Law Review, 215-294.

Kramer, L. D. (2001). The Supreme Court 2000 Term Foreword: We the Court. Harvard Law review, 115, 4-169.

Lawson, G. (1994). The Constitutional Case Against Precedent. Harvard Journal of Law \& Public Policy, 17(1), 23-33.

Polanyi, K. (1944). The Great Transformation: The Political and Economic Origins of Our Time. Boston. Beacon Press.

Posner, R. A. (1983). The Meaning of Judicial Self-Restraint. Indiana Law Journal, 59(1), $1-25$.

Remington, G. (2002). The Sting of Originalism: Defending Legislating from the Bench, Justice and Law. Scalet S. P. (ed.). Birmingham, New York: Global Academic Publishing. Testen, F. (2002). Interpretative judgement. In Šturm, L. (ed.). Komentar Ustave Republike Slovenije. Ljubljana: FPDEŠ.

Tiedmann, P. (2003). Načelo socialne države v nemški ustavi: Navodilo sodstvu ali le argumentativni okras? Družboslovne razprave, XIX(42), 95-107.

Tushnet, M. (2000). Taking the Constitution Away from the Courts. Princeton University Press.

Tümay, M. (2008). The »Margin of Appreciation Doctrine« Developed by the case Law of the European Court of Human Rights. Ankara Law Review, 5(2), 201-234.

Tyler, A. L. (2006). Is Suspension a Political Question. Stanford Law Review, 59(2), $333-413$. 